Published in final edited form as:

Cancer J. 2019 ; 25(3): 179-190. doi:10.1097/PPO.0000000000000378.

\title{
TCR-based Immunotherapy for Hematologic Malignancies
}

\author{
Melinda A Biernacki ${ }^{1,2}$, Michelle Brault ${ }^{1}$, and Marie Bleakley ${ }^{1,3,{ }^{*}}$ \\ ${ }^{1}$ Clinical Research Division, Fred Hutchinson Cancer Research Center, Seattle, WA \\ ${ }^{2}$ Department of Medicine, University of Washington, Seattle, WA \\ ${ }^{3}$ Department of Pediatrics, University of Washington, Seattle, WA
}

\section{Unstructured abstract}

Adoptive immunotherapy with engineered $\mathrm{T}$ cells is at the forefront of cancer treatment. $\mathrm{T}$ cells can be engineered to express $\mathrm{T}$ cell receptors (TCR) specific for tumor-associated antigens (TAAs) derived from intracellular or cell surface proteins. T cells engineered with TCRs (TCR-T) allow for targeting diverse types of TAAs, including proteins overexpressed in malignant cells, those with lineage-restricted expression, cancer-testis antigens, and neoantigens created from abnormal, malignancy-restricted proteins. Minor histocompatibility antigens can also serve as TAAs for TCR-T to treat relapsed hematologic malignancies after allogeneic hematopoietic cell transplantation. Moreover, TCR constructs can be modified to improve safety and enhance function and persistence of TCR-T. TCR-T therapies targeting three different TAAs are in early phase clinical trials for treatment of hematologic malignancies. Preclinical studies of TCR-T specific for many other TAAs are underway and offer great promise as safe and effective therapies for a wide range of cancers.

\section{Keywords}

$\mathrm{T}$ cell immunotherapy; engineered $\mathrm{T}$ cell receptor; hematologic malignancies; tumor-associated antigen

\section{Introduction}

The importance of $\mathrm{T}$ cells in cancer immunity is well-established. $\mathrm{T}$ cells recognize antigens that are short peptides derived from intracellular or cell surface proteins, presented in complex with major histocompatibility complex (MHC) molecules, also referred to as human leukocyte antigens (HLA) on human cells. Spontaneous T cell responses to a variety of cancer antigens have been observed, including in early murine models where exposure to

\footnotetext{
*Corresponding author: Marie Bleakley, MD PhD, Fred Hutchinson Cancer Research Center, 1100 Fairview Avenue N, Mailstop D3-100, Seattle, WA 98109, mbleakle@ fredhutch.org, Phone: (206) 667-6572, Fax: (206) 667-7983.

Conflict of interest statement: M.B. (Bleakley) has received compensation from Miltenyi Biotec for presentations at conferences and corporate symposia pertaining to research unrelated to that presented in the current manuscript. M.B. (Bleakley) and M.A.B. have filed a provisional patent application number 62/616,261 covering applications of T cell immunotherapy for CBF AML. M.B. (Bleakley) has filed a provisional patent application number 62/399,291 covering applications of engineered $\mathrm{T}$ cell receptor for targeting minor histocompatibility (H) antigen HA-1 and compositions for treating leukemia and PCT/US2017/053112 covering applications of TCRs specific for minor histocompatibility $(\mathrm{H})$ antigen HA-1 and uses thereof.
} 
viable or lethally irradiated tumor induced protective immunity against subsequent tumor exposure. ${ }^{1}$ Endogenous $\mathrm{T}$ cell responses also occur in patients, but are often incompletely effective against advanced malignancies. Multiple mechanisms mediate tumor escape and/or block the formation of efficacious anti-tumor immune responses. These mechanisms include induction of a metabolically hostile tumor microenvironment, recruitment of suppressor cells, such as macrophages, regulatory $\mathrm{T}$ cells and myeloid-derived suppressor cells, production of immunosuppressive cytokines, expression of $\mathrm{T}$ cell inhibitory ligands by tumor or associated cells, and deletion of antigen-specific T cells. ${ }^{2-4}$ Acute myeloid leukemia (AML), for example, produces an immunologically hostile environment ${ }^{5}$ through multiple mechanisms such as overexpressing indoleamine 2,3 dioxygenase $1^{6}$ and secreting arginase $\mathrm{II}^{7}$ to metabolically suppress $\mathrm{T}$ cells, overexpressing the PD-L1 T cell-inhibitory molecule ${ }^{8}$ and blocking transcription factor activities needed for $\mathrm{T}$ cell activation and proliferation. ${ }^{9}$ Immunosuppressive microenvironments have also been observed in other hematologic malignancies, including chronic myeloid leukemia (CML) ${ }^{10}$ and chronic lymphocytic leukemia (CLL). ${ }^{11}$ Consequently, $\mathrm{T}$ cells that could mediate anti-tumor immune responses become quantitatively or qualitatively defective. Adoptive transfer of $\mathrm{T}$ cells with tumor specificity is one approach to overcoming such deficiencies in endogenous anti-tumor immunity.

\section{Adoptive T cell therapy for cancer treatment}

To take advantage of naturally occurring $\mathrm{T}$ cell responses, one can isolate tumor-infiltrating lymphocytes (TIL) from tumor, activate and expand the T cells ex vivo, and re-infuse the resulting TIL product, ${ }^{12-15}$ producing clinical responses in some patients. The technology is limited primarily to solid tumors with surgically accessible lesions, although marrowinfiltrating lymphocytes (MIL) are being tested as a therapeutic for hematologic malignancies. ${ }^{16,17}$ However, neither TIL nor MIL can be generated for all patients. ${ }^{18,19}$ Moreover, the specificities of infused TIL/MIL are generally undefined, and a minority of the $\mathrm{T}$ cells are tumor-reactive. ${ }^{20} \mathrm{In}$ contrast, $\mathrm{T}$ cells can be modified to express cell surface receptors that confer specific recognition of a malignant cell target, allowing administration of a $\mathrm{T}$ cell product with a defined specificity and composition. ${ }^{21,22}$ Chimeric antigen receptors (CARs) are artificial antigen-specific receptors consisting of an extracellular ligand-binding domain linked to a $\mathrm{CD} 3 \zeta$ chain along with one or more costimulatory domains ${ }^{23,24}$ that can be transferred into $\mathrm{T}$ cells to produce an engineered $\mathrm{T}$ cell (CAR-T) with defined specificity for a cell surface molecule. Alternatively, $\mathrm{T}$ cells can be engineered to express a transgenic $\mathrm{T}$ cell receptor (TCR-T) specific for a tumor-associated antigen (TAA) formed from the complex of a tumor peptide and an MHC molecule (pMHC). Natural TCRs, from which transgenic TCRs are derived, consist of heterodimers of alpha and beta chains expressed in complex with CD3 proteins (Figure 1), and associate with CD4 or CD8 co-receptors during pMHC engagement and often with costimulatory molecules, such as CD28.

Both CAR-T and TCR-T are adoptive cellular therapies with a defined, pre-selected target; both are often employed with a defined cell composition and can be generated for most patients in which the appropriate target is expressed. Each approach has advantages and disadvantages (Table 1). The major advantage for TIL/MIL and TCR-T over CAR-T is the 
ability to target peptides derived from intracellular proteins or cell surface proteins. Not all malignancies will have a suitable target for CAR-T therapy; that is, a surface molecule with high expression on tumor but low or absent expression on normal tissue, unless the normal tissue is dispensable. In contrast, TCR-T can allow access to the intracellular malignant proteome. CAR-T, however, are MHC/HLA-independent and therefore can be used in patients of all HLA types. CARs are expressed at higher surface levels than TCRs, but have less efficient signaling kinetics that do not properly recapitulate physiological TCR signaling leading to lower sensitivity to antigen. ${ }^{25,26}$ Harris and colleagues engineered two TCRs with high affinity for two distinct TAAs and compared the function of the TCRs either as conventional a $\beta$ TCRs or as the ligand-binding domain of CAR constructs. Although the CAR constructs had similar binding affinity to $\alpha \beta$ TCRs, primary T cells expressing the TCRs secreted cytokine in response to 100-fold lower peptide concentrations than T cells expressing the equivalent CAR. ${ }^{25}$ Additionally, at high antigen density, CAR-T mediate greater maximal release of some cytokines, such as interleukin (IL)-2 and IL- $6,{ }^{25}$ which can initiate a cascade leading to toxic cytokine release syndrome (CRS). TCR-Ts harness an endogenous $\mathrm{T}$ cell response that has been fine-tuned by the evolution of the immune system and are rarely associated with clinically significant CRS.

\section{Antigen targets of T cell receptors for immunotherapy}

\section{Antigen processing and presentation}

T cell antigens are generated from full-length proteins through a multi-step intracellular process (Figure 2 ) that has been extensively reviewed. ${ }^{27-29} \mathrm{CD} 8^{+} \mathrm{T}$ cell antigens are primarily derived from endogenous proteins that are degraded in the cytoplasm by proteasomes and cytosolic aminopeptidases. The resulting peptides are transported into the endoplasmic reticulum (ER) through the transporter associated with antigen processing (TAP) complex, where they are trimmed by ER aminopeptidases (ERAPs) into lengths of 810 amino acids. While we have a detailed understanding of how processing occurs, the exact rules of trimming and processing are not well understood. Trimmed peptides are assembled with MHC class I heavy chain and beta- 2 microglobulin via a peptide-loading complex. The pMHC class I complex then transits from the ER to the plasma membrane, where it is presented externally. $\mathrm{CD}^{+} \mathrm{T}$ cell antigens can also be generated from viral proteins in infected cells and from misfolded or improperly synthesized proteins. Additionally, certain antigen-presenting cells can present peptides from internalized exogenous proteins on MHC class I molecules through cross-presentation. TAA are potentially present on all malignant cells, regardless of the tissue of origin, because MHC class I molecules are ubiquitously expressed on all nucleated cells. However, downregulation and loss of class I MHC expression are established mechanisms of immune evasion by tumors. ${ }^{30-38} \mathrm{CD} 8^{+} \mathrm{T}$ cells are directly cytotoxic, making MHC class I restricted TAA particularly attractive as immunotherapy targets.

In contrast, $\mathrm{CD} 4^{+} \mathrm{T}$ cells recognize peptides presented on MHC class II molecules. Peptides are loaded onto MHC Class II after degradation of internalized exogenous proteins or autophagy of endogenous proteins. ${ }^{39}$ Class II molecules are normally expressed on antigenpresenting and hematopoietic cells, including AML. This review will focus on class I- 
restricted $\mathrm{CD} 8^{+} \mathrm{T}$ cell antigens, since these are the majority of targets in preclinical and clinical development for TCR-T therapies for hematologic malignancies. However, class II restricted antigens also appear to have a role in antitumor immunity. Downregulation of MHC class II expression ${ }^{40}$ or complete loss of a mismatched MHC haplotype ${ }^{41}$ can occur in leukemic relapses after allogeneic hematopoietic stem cell transplantation (allo-HCT), suggesting that class II antigens contribute to disease control after allo-HCT. Upregulation of class II expression been described for some solid tumors, ${ }^{42-45}$ and, in melanoma, is associated with increased probability of response to immune checkpoint blockade therapy ${ }^{46}$ Adoptive transfer of TIL enriched for $\mathrm{CD}^{+} \mathrm{T}$ cells specific for a mutation in erbb2interacting protein produced striking clinical responses in one patient with metastatic cholangiocarcinoma. ${ }^{47}$ As we learn more about class II-restricted TAAs, these too may prove to be relevant targets in hematologic malignancies.

\section{Classes of T cell antigens for TCR-based immunotherapy}

An ideal target for any cell-based immunotherapy is one that is selectively presented on malignant cells, necessary for survival of the tumor cells, and shared amongst patients. Four major TAA classes have been considered as targets for TCR-T immunotherapy in solid and liquid tumors: 1) overexpressed antigens derived from wild-type proteins with relatively high expression in malignant cells; 2) lineage-restricted antigens that are also presented on the normal counterparts of the malignant cells; 3 ) cancer-testis antigens (CTA), which are normally expressed in germline tissues and aberrantly expressed in malignant cells; and 4) neoantigens created from abnormal proteins (mutations, fusions, frameshifts, or novel isoforms) or abnormal peptides specific to the malignant cells. Antigen specificity for malignant versus healthy cells varies among the categories of TAAs (Table 2), and the potential risk of on-target, off-tumor toxicity inversely corresponds to that specificity. Specific examples of TAAs in each category are shown in Table 3.

In hematologic malignancies, minor histocompatibility $(\mathrm{H})$ antigens are a fifth important class of TAAs. Minor H antigens are MHC/HLA-bound polymorphic peptides that differ between allo-HCT recipient and donor as a result of genetic polymorphisms. Once full donor normal hematopoietic chimerism is achieved after allo-HCT, hematopoietic-restricted minor $\mathrm{H}$ antigens are present only on residual recipient malignant hematopoietic cells, providing significant specificity when donor and recipient are mismatched for the polymorphism. Like lineage-restricted antigens, the specificity of minor $\mathrm{H}$ antigens for malignant cells depends on how tightly restricted expression of the parent protein is to hematopoietic cells. Therapies targeting minor $\mathrm{H}$ antigens could potentially treat multiple hematologic malignancies, since the antigens are not disease specific. However, varying polymorphism frequencies across populations and the requirement for donor-recipient mismatch currently limits the applicability of minor H-directed immunotherapy to a subset of individuals who relapse after allo-HCT.

\section{General considerations in developing TCR immunotherapy}

Transgenic TCR development begins by discovering and cloning a naturally occurring TCR specific for a suitable target. Generally, there are three starting pools of cells in which to 
identify a relevant TCR: patient TIL/MILs, patient peripheral blood T cells, and healthy donor peripheral blood $\mathrm{T}$ cells requiring primary in vitro stimulation. ${ }^{48,49} \mathrm{TIL} / \mathrm{MILs}$ can be used as a source of T cells potentially enriched for TAA-specific TCRs, but T cells derived from immunosuppressive tumor environments are often dysfunctional. ${ }^{50}$ Stimulating healthy donor $\mathrm{T}$ cells with known or predicted novel TAAs in vitro to isolate reactive $\mathrm{T}$ cells and their TCRs can circumvent $\mathrm{T}$ cell dysfunction.

To determine reactivity to a specific target, binding and functionality are tested by measuring pMHC multimer binding, cytotoxicity, and/or cytokine production by ELISPOT or flow cytometry. Newer methods like barcoded dextramer staining ${ }^{51}$ allow screening hundreds of pMHC complexes from one sample. Once responding T cells are found, the TCR sequence must be determined and cloned. Rapid amplification of cDNA ends before polymerase chain reaction (RACE-PCR) allows identification of the TCR $\alpha$ and $\beta$ chains of a reactive T cell clone. Contemporary approaches like single-cell sequencing can directly identify the TCR sequences of individual clones in a bulk population. The Wu group paired single-cell sequencing with a library of cloning plasmids for each TCRa/TCR $\beta$ chain to reconstruct TCRs from a bulk population and rapidly deconvolute TCR specificity and avidity for a target antigen, ${ }^{52}$ allowing TCRs to be screened against relevant targets at an accelerated pace compared to traditional methods.

After sequencing a reactive TCR, the receptor must be transferred to a new T cell.

Transduction with a viral vector encoding a polycistronic construct of both $a$ and $\beta$ chains of the transgenic TCR separated by a ribosomal skip motif, such as a $2 \mathrm{~A}$ self-cleaving peptide, is most commonly used. Nonviral techniques for TCR gene transfer, such as transposonbased technologies ${ }^{53-55}$ and nanoparticles, ${ }^{56}$ are also in development. In any case, conventional $\mathrm{T}$ cells that are genetically modified with a transgenic TCR have their own endogenous TCRs, making mispairing of the transferred and endogenous TCRs a concern. In preclinical studies using an OT-I TCR murine model, mispairing of the endogenous TCR with the transferred TCR led to lethal graft-versus-host disease (GVHD), ${ }^{57}$ although GVHD due to TCR mispairing has not been observed in human trials to date. The risk of mispairing can be mitigated by introducing cysteine modifications to the transferred TCR $a$ and $\beta$ chains to favor pairing of the introduced chains to each other. Other potential modifications to the TCR construct include codon optimization and minimal murinization of the constant region $^{58}$ to enhance expression of the transgenic TCR and encourage correct pairing of the introduced chains. Alternatively, using small interfering RNA (siRNA) and CRISPR/Cas9 to disrupt the endogenous TCR has been shown to limit toxicity and increase T cell activity in humanized mouse models. ${ }^{59}$ While eliminating the endogenous TCR prevents mispairing, it is unclear whether retaining an endogenous TCR might help transferred T cells persist when antigen burden is low. However, it is clear that designing transgenic TCRs for exclusive selfpairing is paramount to limiting autoimmunity and toxicity.

Many native TCRs recognize overexpressed self-antigens with inherently low affinity due to tolerance mechanisms. In vitro affinity maturation can enhance target recognition, ${ }^{60-62}$ although with increased risk of cross-reactivity and off-target toxicity. In a clinical trial of an affinity-matured MAGE-A3-specific TCR, transgenic T cells also recognized the Titin cardiac protein and led to the death of two patients. ${ }^{63}$ The native, non-matured TCR did not 
recognize cardiac tissue, ${ }^{64}$ highlighting the relationship between augmented affinity and potential cross-reactivity. Which complementary-determining regions (CDRs) are altered in affinity maturation may influence the risk of cross-reactivity and toxicity. CDR1 and CDR2 interact predominantly with MHC; alterations in these regions can increase TCR binding of MHC regardless of peptide. ${ }^{65,66}$ In contrast, CDR3 interacts predominantly with peptide, ${ }^{67}$ so affinity maturation targeting this region might produce higher affinity TCRs with less likelihood of cross-reactivity, although experimental data is limited. A recent approach to developing TCRs with highly diverse CDR3s used in vitro antigen-driven differentiation of progenitor $\mathrm{T}$ cells to generate higher affinity TCRs without changes to CDR1/2. ${ }^{68}$ Safety testing of TCRs generated in this manner may lead to better understanding of the relationship between cross-reactivity and affinity.

As our understanding of natural and synthetic $\mathrm{T}$ cell biology increases, investigators are testing numerous modifications that might improve the functionality, persistence, and safety of transferred T cells (Figure 4). Introducing a CD8 co-receptor can facilitate recognition of class I antigens by $\mathrm{CD} 4^{+} \mathrm{T}$ cells, and enhance 'help' for cytotoxic $\mathrm{CD} 8{ }^{+} \mathrm{T}$ cells. ${ }^{69-74}$ Safety switches, including inducible pro-death proteins, can be used to rapidly remove transferred $\mathrm{T}$ cells if toxicities such as CRS or GVHD become an issue. ${ }^{75-80}$ The ability to secrete IL-12 and other cytokines can increase activity of so-called 'armored' CAR-T or TCR-T cells and create a proinflammatory environment that enables antigen presentation, ${ }^{81-83}$ albeit with an increased potential for toxicity if cytokine secretion is not tightly regulated. ${ }^{84}$ Function of transferred $\mathrm{T}$ cells can also be increased by siRNA or CRISPR-Cas9 elimination of inhibitory molecule genes, such as PD-1, 85,86 or by converting negative malignant cellderived signals into activation signals for engineered $\mathrm{T}$ cells, for example by fusing the inhibitory receptor CD200R to a costimulatory CD28 domain. ${ }^{87}$ Normal signaling pathways, such as thrombopoietin and c-MPL, ${ }^{88}$ can also be co-opted to deliver an activating signal to engineered T cells through the transgene construct. 'Off-the-shelf' versions of engineered cells that are HLA negative and express natural killer (NK) cell inhibitory molecules could be used as universal donor cells, ${ }^{89}$ potentially eliminating the need for autologous cell collection from patients, although silencing the endogenous TCR will likely be required in this situation to prevent GVHD.

\section{TCR immunotherapy in hematologic malignancies}

A recent systematic review estimated that only $16 \%$ of previous and current TCR-T clinical trials were aimed at treating hematologic malignancies. ${ }^{90}$ However, numerous preclinical studies are presently underway. Suitable TCR targets must be highly expressed on malignant cells, including blasts, progenitor and cancer stem cells, and have little or ideally no expression on healthy non-hematopoietic tissues. However, expression of the target antigen on normal hematopoietic cells may be acceptable in select circumstances; for example, if: 1) expression is sufficiently low that high-avidity T cells will not recognize normal cells; 2 ) the normal cells are relatively dispensable, as in the case of normal B cells; 3) the normal cells do not express HLA molecules (e.g. testis); or, 4) TCR immunotherapy expected to cause myelolablation will be used prior to allo-HCT and the TCR-T cells are designed to be shortlived. Because the field is still evolving and the optimal antigens for TCR immunotherapy are as-yet unknown, target candidates from all TAA categories are being explored (Table 3). 


\section{Clinical development of TCR immunotherapies}

WT1 TCR immunotherapy-Wilm's tumor 1 (WT1) protein is overexpressed in acute leukemias and myelodysplastic syndromes (MDS) ${ }^{91}$ and has limited expression on normal tissues, including normal $\mathrm{CD} 34^{+}$hematopoietic stem cells. T cells specific for WT1 epitopes that are presented on HLA-A $* 24: 02^{92}$ or $-\mathrm{A} * 02: 01^{93,94}$ recognize primary leukemic blasts, making WT1 an attractive therapeutic target. Donor-derived T cell responses to WT1 have been observed in vivo after allo-HCT. ${ }^{94} \mathrm{WT} 1$-specific $\mathrm{CD} 8^{+} \mathrm{T}$ cell responses can be stimulated ex vivo, and retain their activity in vivo. ${ }^{95,96}$ The Chapuis and Greenberg group adoptively transferred ex vivo expanded, donor-derived $\mathrm{CD} 8^{+} \mathrm{T}$ cells specific for an HLA$\mathrm{A} * 02: 01$-restricted WT1 epitope in a cohort of eleven patients with relapsed or high-risk acute leukemia or MDS after allo-HCT (NCT00052520). ${ }^{97}$ Transferred T cells were well tolerated, indicating minimal on-target off-tumor toxicity, persisted and showed direct (disease response) or indirect (absence of relapse) anti-leukemic activity in five patients. Other clinical trials of ex vivo expanded or sensitized WT1-specific T cells for high-risk leukemias and multiple myeloma are ongoing (NCT00620633, NCT01758328).

Chapuis, Greenberg and coworkers next developed transgenic TCR-T cells directed against an HLA-A*02:01-restricted WT1 epitope for prevention or treatment of AML relapse after allo-HCT. To generate WT1-specific T cells, cytomegalovirus- or Epstein Barr virus-specific $\mathrm{T}$ cells from the HCT donor were transduced with a native, high-affinity, WT1-specific TCR identified from the peripheral repertoires of a healthy HLA-A*02:01+ individual. In a phase 1 clinical trial (NCT01640301), eleven patients with high-risk AML were treated prophylactically with WT1 TCR-T cells, and none had relapsed at a median follow-up of 21.3 months after allo-HCT, compared to $27 \%$ relapse at 16 months among matched controls. ${ }^{98,99}$ No survival advantage over standard of care was seen in patients treated with WT1 TCR T cells at relapse in preliminary findings. The Tawara group developed a retroviral construct encoding a high-affinity WT1/HLA-A*24:02-specific TCR identified from the peripheral repertoire of a healthy individual, ${ }^{92}$ along with siRNAs to eliminate expression of endogenous TCR chains. ${ }^{100}$ In a phase 1 clinical trial (UMIN000011519), eight patients with chemotherapy-refractory AML or high-risk MDS were treated with escalating doses (1.2-3.5× $10^{8}$ cells per infusion) of autologous T cells expressing the WT1 TCR construct. No toxicity was observed, WT1 TCR T cells persisted in five patients, and transient decreases were noted in the percentage of bone marrow leukemic blasts in two patients. These data suggest that adoptively transferred WT1 TCR T cells directed against either HLA-A*02:01 or -A*24:02-restricted WT1 epitopes are safe, well-tolerated and may have anti-leukemic activity in vivo.

PRAME TCR immunotherapy-The PRAME CTA is overexpressed on solid tumors and in acute lymphoblastic leukemia (ALL), AML and MDS. ${ }^{101,102} \mathrm{~A}$ high-avidity TCR specific for an HLA-A*02:01-restricted, PRAME-derived epitope was identified from the T cell repertoire of an HLA-A*02:01-negative donor after transplantation and subsequent donor lymphocyte infusion into an HLA-A*02:01-positive recipient. ${ }^{103}$ The parental clone from which this TCR was isolated could recognize primary AML and ALL samples, as well as solid tumor cell lines, but did not recognize normal tissues except for mature dendritic cells and kidney epithelial cells. Retroviral transfer of the TCR conferred functional avidity and 
recognition of target cell lines similar to that measured for the parental clone. An early phase clinical trial of adoptive transfer of PRAME/A*02:01 TCR-transduced autologous T cells (BPX-701, Bellicum Pharmaceuticals) to treat AML, MDS and uveal melanoma opened in 2017 (NCT02743611). A second PRAME/A*02:01-specific TCR was isolated independently by another group; ${ }^{104}$ an early phase clinical trial testing autologous $\mathrm{T}$ cells expressing this TCR for treatment of high-risk AML, MDS and multiple myeloma opened in 2017 in Germany (NCT03503968).

HA-1 T cell immunotherapy-Hematopoietic-restricted minor $\mathrm{H}$ antigens can function as TAA in the context of recurrence after allo-HCT, assuming that donor and recipient have a suitable genotype mismatch. The minor $\mathrm{H}$ antigen $\mathrm{HA}-\mathrm{1}^{\mathrm{H}}$ (hereafter referred to as HA-1) is encoded by a DNA sequence spanning a single nucleotide polymorphism (RS_1801284) within the HMHA1 gene. The resulting immunogenic peptide, VLHDDLLEA, is efficiently presented by HLA-A*02:01; the corresponding allelic variant peptide, VLRDDLLEA, has lower affinity for and unstable binding to HLA-A*02:01. The $H M H A 1$ protein product is expressed in normal and malignant hematopoietic cells, but not in non-hematopoietic cells. In HA-1-mismatched allo-HCT, high-avidity HA-1-specific T cells from a HA-1-negative donor can be primed against HA-1 and mediate a graft-versus-tumor effect, as evidenced by decreased relapse rates in HA-1 mismatched allo-HCT (donor negative, recipient positive) and expansion of HA-1-specific T cells after donor lymphocyte infusion for post-allo-HCT relapses. ${ }^{105}$ A high-avidity, HA-1-specific TCR was identified from the repertoire of a healthy HLA-A*02:01-positive HA-1-negative individual and was sequenced and cloned into a lentiviral vector, along with a selection marker, safety switch (iCasp9) and CD8 coreceptor, to allow TCR-transduced $\mathrm{CD}^{+}{ }^{+} \mathrm{T}$ cells to recognize the MHC class I-restricted epitope. $\mathrm{CD} 8^{+}$and $\mathrm{CD} 4^{+} \mathrm{T}$ cells expressing the HA-1 TCR construct were highly functional against leukemia cell lines and primary leukemia in vitro and could be rapidly eliminated using the safety switch. ${ }^{69}$ A phase 1 clinical trial of $\mathrm{CD} 8^{+}$and $\mathrm{CD} 4^{+} \mathrm{T}$ cells transduced with this HA-1 TCR construct is now open to patients with hematologic malignancies (NCT03326921). HA-1 TCR T cell immunotherapy is also being evaluated in the Netherlands, using a different HA-1-specific TCR, a different transgene (without CD8 coreceptor) and viral vector (retroviral rather than lentiviral), and a different cell product (EudraCT number 2010-024625-20).

\section{Preclinical development of TCR immunotherapies Overexpressed antigens}

Survivin: Survivin is a member of the inhibitors of apoptosis protein family that is overexpressed in numerous cancers, including AML ${ }^{106-108}$ and various lymphomas, ${ }^{109,110}$ where its overexpression correlates with poor prognosis. High-affinity TCRs specific for an HLA-A*02:01-restricted survivin epitope were identified by stimulating HLA-A*02:01negative $\mathrm{CD} 8^{+} \mathrm{T}$ cells with autologous dendritic cells transfected to express HLA-A*02:01. While transfer of TCRs isolated by this method enabled recognition and lysis of survivinpositive tumor cell lines, transfer of high-affinity TCRs also produced HLA-restricted fratricide of HLA-A*02:01-positive T cells. ${ }^{111}$ To overcome this obvious limitation, another group subsequently used stimulation with autologous dendritic cells to identify survivinspecific, HLA-A*02:01-restricted T cells from HLA-A*02:01-positive individuals. ${ }^{112}$ 
Adoptive transfer of $\mathrm{T}$ cells transduced to express survivin-specific TCRs thus isolated showed antileukemic activity and prolonged survival in immunodeficient murine xenograft models of AML. ${ }^{112}$

Human telomerase reverse transcriptase (hTERT): hTERT is a catalytic subunit for telomere elongation that is expressed in numerous hematologic malignancies, but not in normal tissues. ${ }^{113-115}$ Two hTERT epitopes have been investigated as targets for transgenic TCR immunotherapy. A high-avidity TCR specific for an HLA-A*24:02-specific hTERT epitope ${ }^{116}$ was identified from the repertoire of a healthy individual by autologous stimulation, and subsequently cloned into a retroviral vector that also included siRNAs to eliminate expression of endogenous TCR chains. ${ }^{117}$ Adoptive transfer of hTERT TCR-T cells into an immunodeficient murine xenograft model of HTLV-associated T cell leukemia (ATL) inhibited tumor outgrowth for $>6$ months. In separate studies, a murine TCR specific for an HLA-A*02:01-restricted hTERT epitope was isolated by hTERT vaccination of HLA$\mathrm{A}^{*}$ 02:01-expressing transgenic mice ${ }^{118}$ and cloned into a retroviral vector. ${ }^{119}$ Adoptive transfer of human $\mathrm{T}$ cells transduced with the hTERT-specific TCR showed in vivo activity against CLL ${ }^{119}$, B cell ALL, and AML ${ }^{120}$ in murine models. Although we are not aware of any TCR-T clinical trials targeting hTERT, clinical trials of hTERT vaccination are underway in the U.S. and Europe.

BOB1: BOB1 is a B cell-specific transcription factor that is highly expressed in B cell leukemias and lymphomas, as well as in multiple myeloma. A TCR specific for an HLA$\mathrm{B} * 07: 02$-restricted $\mathrm{BOB} 1$ epitope was identified from the alloreactive repertoire of a healthy individual and transferred into a retroviral vector. ${ }^{121}$ The transferred TCR enabled selective recognition and killing of BOB1-positive primary B cell leukemia, mantle cell lymphoma and multiple myeloma cells in vitro. Adoptive transfer of BOB1 TCR-transduced CD8 $8^{+} \mathrm{T}$ cells also controlled tumor outgrowth in an immunodeficient murine xenograft model of established myeloma. ${ }^{121}$

Lineage-restricted: Targeting lineage-restricted antigens in myeloid malignancies can cause myeloablation, necessitating allo-HCT to rescue hematopoiesis. However, in B cell malignancies, targeting of lineage-restricted antigens is more feasible because healthy B cells are dispensable. While this capacity has been exploited most thoroughly in the development of CAR-T cell therapy (CD19-, CD22-, and CD20-directed), B cell-restricted antigens can also be targeted by TCR-based approaches. Transfer of an HLA-B*07:02restricted CD20 epitope-specific TCR enabled recognition of CD20-positive malignant cell lines and primary tumors (CLL, ALL, and mantle cell lymphoma), and suggested that TCRbased approaches may be effective in low expression CD20-positive B cell malignancies. ${ }^{122}$ $T$ cells transduced with a different TCR specific for an HLA-B*07:02-restricted CD22 epitope killed primary B cell leukemia cells, but also killed healthy dendritic cells and macrophages, ${ }^{123}$ illustrating both the potential promise and limitation of targeting lineagerestricted antigens.

Cancer-testis antigens: Aurora kinase A (AurA) is a serine-threonine kinase involved in mitotic cell division, which among normal tissues is only detected in testis only, but is 
expressed at high levels in leukemias. ${ }^{124,125}$ An epitope derived from amino acids 207-215 of AurA is presented on HLA-A*02:01 and $-\mathrm{A} * 24: 02$ on primary myeloid leukemia, and $\mathrm{CD} 8{ }^{+} \mathrm{T}$ cells specific for this epitope lyse leukemia cells in vitro. ${ }^{125} \mathrm{~A}$ TCR specific for the HLA-A*02:01-restricted AurA epitope was identified in a healthy donor, and retroviral transfer of this TCR enabled in vitro recognition of leukemia by transgenic $\mathrm{CD} 4^{+}$and $\mathrm{CD} 8^{+}$ T cells. ${ }^{126}$ The $\mathrm{CD} 8^{+}$AurA TCR-T cells also controlled leukemia progression in vivo in an immunodeficient murine xenograft model. Of note, AurA TCR-T cells may also be applicable as immunotherapy in ATL. 127

Neoantigens: In contrast to solid tumors, which may carry hundreds or even thousands of mutations in an individual patient, ${ }^{128}$ most hematologic malignancies have relatively few protein-coding mutations or gene fusions, and thus fewer potential neoantigens. However, for TCR-T immunotherapy, a small number of neoantigens will suffice, as long as those neoantigens are shared among patients and ideally occur early in oncogenesis or are essential in maintaining the malignant phenotype. For example, the type A variant of the CBFB-MYH11 fusion is critical in leukemogenesis, and occurs in $~ 10 \%$ of individuals with AML and $\sim 90 \%$ of AML patients with the inv(16) or $\mathrm{t}(16 ; 16)$ cytogenetic abnormalities. An epitope spanning the CBFB-MYH11 fusion region is presented on HLA-B*40:01 and enables selective recognition and killing of leukemic blasts by epitope-specific $\mathrm{T}$ cells. Lentiviral transfer of a high-avidity TCR confers epitope specificity and antileukemic cytotoxicity in vitro, suggesting that CBFB-MYH11 is a viable target for TCR-based immunotherapy for a subset of patients. ${ }^{129}$ Targeting the fusion may enable eradication of the cell of origin, as it is known to play a key role in maintaining the leukemic phenotype.

An epitope derived from a highly recurrent frameshift mutation in exon 12 of nucleophosmin 1 (NPM1) is another potential neoantigen target for TCR immunotherapy. NPM1 mutations occur in 30-35\% of AML cases and are early events that persist across the disease course. $\mathrm{CD} 8^{+} \mathrm{T}$ cells specific for an HLA-A*02:01-restricted NPM1 epitope can selectively recognize NPM1-mutated leukemic blasts, and adoptive transfer of NPM1/HLAA*02:01 specific TCR-transduced T cells controlled tumor outgrowth and prolonged survival in an immunodeficient murine xenograft model. ${ }^{130}$ These early studies suggest a role for shared neoantigens in TCR-based immunotherapy of AML and other hematologic malignancies.

\section{Future of TCR immunotherapy in hematologic malignancies}

TCR-T cell immunotherapy is a very young field but is evolving quickly. Advances in the fields of basic immunology, protein science, synthetic biology, genomics, and cell and genome engineering should allow us to overcome many previously-recognized obstacles and facilitate the development of TCR-T therapies. One major bottleneck has been identifying bona fide target epitopes with sufficient cancer-specificity for safe targeting in patients. In silico algorithms can effectively predict binding of peptides to MHC/HLA molecules, but not whether the peptides are processed and presented on cell surfaces. With the wave of 'omic' approaches, some have attempted to determine the 'peptidome' of malignant cells by immunoprecipitating MHC complexes, eluting peptides from these complexes and identifying peptides by tandem liquid chromatography-mass spectrometry. ${ }^{131-133}$ This 
unbiased approach can identify peptides naturally processed and presented on cells of interest, but also has technical hurdles. ${ }^{134-136}$ Improving techniques to identify and characterize the peptidome of malignant cells, such as the use of monoallelic cells, ${ }^{134}$ has the potential to fast-track discovery of physiologically-relevant targets for TCR-T immunotherapy. TCR sequencing techniques are rapidly evolving, as is our understanding of how to predict which pMHC complexes functionally engage specific TCR sequences. ${ }^{137}$ Although these technologies are early in development, understanding the biophysical and structural rules that govern TCR-pMHC binding will also improve prediction of crossreactivity to other pMHC complexes and thus uncover potential off-target toxicities, and may even allow rational design of synthetic target-specific TCRs in the future.

Currently, all TCR-T immunotherapies target single antigens, running the risk the cancer may simply escape recognition by downregulating expression of the target protein, as seen in CD19 CAR-T cell trials. ${ }^{138,139}$ TCR-T targeting of proteins that are essential to maintaining the leukemic phenotype, like leukemia-initiating fusions, should avoid this escape mechanism. For targets that are less essential to the malignant cell, transferring transgenic TCR-T cells with multiple specificities could reduce the probability of antigen escape. One approach would be to make multiple TCR-T products with different specificities separately and infuse them together into the patient. Another would be to modify T cells to express multiple TCRs, although ensuring correct pairing of introduced TCR chains would be challenging. TCR mimic monoclonal antibodies, which bind specifically to pMHC complexes, can be used as CARs ${ }^{140}$ and might be more readily multiplexed.

\section{Conclusions}

Much progress has been made in the field of TCR-T immunotherapy generally and for hematologic malignancies specifically. Despite the challenges of identifying suitable targets for TCR-T therapies, a number of promising TAAs are under preclinical investigation as targets for TCR-T immunotherapy. Encouragingly, four different TCR-T immunotherapies are now in early phase clinical trials, targeting: WT1 epitopes restricted to HLA-A*02:01 and $\mathrm{A} * 24: 02$; an HLA-A*02:01-restricted PRAME epitope; and the HLA-A*02:01restricted minor $\mathrm{H}$ antigen HA-1. Along with improvements in T cell antigen discovery and cell engineering techniques, gained in part from experience with CAR-T cell therapies, these studies set the stage for development of TCR-T immunotherapies with potent curative potential in the hematologic malignancies.

\section{REFERENCES}

1. Gross L Intradermal Immunization of $\mathrm{C} 3 \mathrm{H}$ Mice against a Sarcoma That Originated in an Animal of the Same Line. Cancer Res 1943;3:326-33.

2. Lemos H, Huang L, Prendergast GC, Mellor AL. Immune control by amino acid catabolism during tumorigenesis and therapy. Nat Rev Cancer 2019;19:162-75. [PubMed: 30696923]

3. van der Burg SH, Arens R, Ossendorp F, van Hall T, Melief CJ. Vaccines for established cancer: overcoming the challenges posed by immune evasion. Nat Rev Cancer 2016;16:219-33. [PubMed: 26965076]

4. Yarchoan M, Johnson BA 3rd, Lutz ER, Laheru DA, Jaffee EM. Targeting neoantigens to augment antitumour immunity. Nat Rev Cancer 2017;17:209-22. [PubMed: 28233802] 
5. Teague RM, Kline J. Immune evasion in acute myeloid leukemia: current concepts and future directions. J Immunother Cancer 2013;1.

6. Fukuno K, Hara T, Tsurumi H, et al. Expression of indoleamine 2,3-dioxygenase in leukemic cells indicates an unfavorable prognosis in acute myeloid leukemia patients with intermediate-risk cytogenetics. Leuk Lymphoma 2015;56:1398-405. [PubMed: 25248875]

7. Mussai F, De Santo C, Abu-Dayyeh I, et al. Acute myeloid leukemia creates an arginase-dependent immunosuppressive microenvironment. Blood 2013;122:749-58. [PubMed: 23733335]

8. Zhang L, Gajewski TF, Kline J. PD-1/PD-L1 interactions inhibit antitumor immune responses in a murine acute myeloid leukemia model. Blood 2009;114:1545-52. [PubMed: 19417208]

9. Buggins AG, Milojkovic D, Arno MJ, et al. Microenvironment produced by acute myeloid leukemia cells prevents $\mathrm{T}$ cell activation and proliferation by inhibition of NF-kappaB, c-Myc, and pRb pathways. J Immunol 2001;167:6021-30. [PubMed: 11698483]

10. Bruck $\mathrm{O}$, Blom $\mathrm{S}$, Dufva $\mathrm{O}$, et al. Immune cell contexture in the bone marrow tumor microenvironment impacts therapy response in CML. Leukemia 2018;32:1643-56. [PubMed: 29925907]

11. Burger JA, Gribben JG. The microenvironment in chronic lymphocytic leukemia (CLL) and other B cell malignancies: insight into disease biology and new targeted therapies. Semin Cancer Biol 2014;24:71-81. [PubMed: 24018164]

12. Dudley ME, Wunderlich JR, Robbins PF, et al. Cancer regression and autoimmunity in patients after clonal repopulation with antitumor lymphocytes. Science 2002;298:850-4. [PubMed: 12242449]

13. Dudley ME, Wunderlich JR, Yang JC, et al. Adoptive cell transfer therapy following nonmyeloablative but lymphodepleting chemotherapy for the treatment of patients with refractory metastatic melanoma. J Clin Oncol 2005;23:2346-57. [PubMed: 15800326]

14. Rosenberg SA, Packard BS, Aebersold PM, et al. Use of tumor-infiltrating lymphocytes and interleukin-2 in the immunotherapy of patients with metastatic melanoma. A preliminary report. $\mathrm{N}$ Engl J Med 1988;319:1676-80. [PubMed: 3264384]

15. Rosenberg SA, Yannelli JR, Yang JC, et al. Treatment of patients with metastatic melanoma with autologous tumor-infiltrating lymphocytes and interleukin 2. J Natl Cancer Inst 1994;86:1159-66. [PubMed: 8028037]

16. Noonan K, Matsui W, Serafini P, et al. Activated marrow-infiltrating lymphocytes effectively target plasma cells and their clonogenic precursors. Cancer Res 2005;65:2026-34. [PubMed: 15753403]

17. Noonan KA, Huff CA, Davis J, et al. Adoptive transfer of activated marrow-infiltrating lymphocytes induces measurable antitumor immunity in the bone marrow in multiple myeloma. Sci Transl Med 2015;7:288ra78.

18. Dudley ME, Gross CA, Langhan MM, et al. CD8+ enriched "young” tumor infiltrating lymphocytes can mediate regression of metastatic melanoma. Clin Cancer Res 2010;16:6122-31. [PubMed: 20668005]

19. Geukes Foppen MH, Donia M, Svane IM, Haanen JB. Tumor-infiltrating lymphocytes for the treatment of metastatic cancer. Mol Oncol 2015;9:1918-35. [PubMed: 26578452]

20. Scheper W, Kelderman S, Fanchi LF, et al. Low and variable tumor reactivity of the intratumoral TCR repertoire in human cancers. Nat Med 2019;25:89-94. [PubMed: 30510250]

21. June CH, O'Connor RS, Kawalekar OU, Ghassemi S, Milone MC. CAR T cell immunotherapy for human cancer. Science 2018;359:1361-5. [PubMed: 29567707]

22. Turtle CJ, Hanafi LA, Berger C, et al. CD19 CAR-T cells of defined CD4+:CD8+ composition in adult B cell ALL patients. J Clin Invest 2016;126:2123-38. [PubMed: 27111235]

23. Kershaw MH, Westwood JA, Darcy PK. Gene-engineered T cells for cancer therapy. Nat Rev Cancer 2013;13:525-41. [PubMed: 23880905]

24. Salter AI, Pont MJ, Riddell SR. Chimeric antigen receptor-modified T cells: CD19 and the road beyond. Blood 2018;131:2621-9. [PubMed: 29728402]

25. Harris DT, Hager MV, Smith SN, et al. Comparison of T Cell Activities Mediated by Human TCRs and CARs That Use the Same Recognition Domains. J Immunol 2018;200:1088-100. [PubMed: 29288199] 
26. Salter AI, Ivey RG, Kennedy JJ, et al. Phosphoproteomic analysis of chimeric antigen receptor signaling reveals kinetic and quantitative differences that affect cell function. Sci Signal 2018;11.

27. Cresswell P Antigen processing and presentation. Immunol Rev 2005;207:5-7. [PubMed: 16181322]

28. Vyas JM, Van der Veen AG, Ploegh HL. The known unknowns of antigen processing and presentation. Nat Rev Immunol 2008;8:607-18. [PubMed: 18641646]

29. Blum JS, Wearsch PA, Cresswell P. Pathways of antigen processing. Annu Rev Immunol 2013;31:443-73. [PubMed: 23298205]

30. Koopman LA, Corver WE, van der Slik AR, Giphart MJ, Fleuren GJ. Multiple genetic alterations cause frequent and heterogeneous human histocompatibility leukocyte antigen class I loss in cervical cancer. J Exp Med 2000;191:961-76. [PubMed: 10727458]

31. Campoli M, Chang CC, Ferrone S. HLA class I antigen loss, tumor immune escape and immune selection. Vaccine 2002;20 Suppl 4:A40-5. [PubMed: 12477427]

32. Garrido F, Ruiz-Cabello F, Aptsiauri N. Rejection versus escape: the tumor MHC dilemma. Cancer Immunol Immunother 2017;66:259-71. [PubMed: 28040849]

33. Shukla SA, Rooney MS, Rajasagi M, et al. Comprehensive analysis of cancer-associated somatic mutations in class I HLA genes. Nat Biotechnol 2015;33:1152-8. [PubMed: 26372948]

34. Benitez R, Godelaine D, Lopez-Nevot MA, et al. Mutations of the beta2-microglobulin gene result in a lack of HLA class I molecules on melanoma cells of two patients immunized with MAGE peptides. Tissue Antigens 1998;52:520-9. [PubMed: 9894850]

35. Sade-Feldman M, Jiao YJ, Chen JH, et al. Resistance to checkpoint blockade therapy through inactivation of antigen presentation. Nat Commun 2017;8:1136. [PubMed: 29070816]

36. Gettinger S, Choi J, Hastings K, et al. Impaired HLA Class I Antigen Processing and Presentation as a Mechanism of Acquired Resistance to Immune Checkpoint Inhibitors in Lung Cancer. Cancer Discov 2017;7:1420-35. [PubMed: 29025772]

37. McGranahan N, Rosenthal R, Hiley CT, et al. Allele-Specific HLA Loss and Immune Escape in Lung Cancer Evolution. Cell 2017;171:1259-71 e11. [PubMed: 29107330]

38. Paulson KG, Voillet V, McAfee MS, et al. Acquired cancer resistance to combination immunotherapy from transcriptional loss of class I HLA. Nat Commun 2018;9:3868. [PubMed: 30250229]

39. Crotzer VL, Blum JS. Autophagy and its role in MHC-mediated antigen presentation. J Immunol 2009;182:3335-41. [PubMed: 19265109]

40. Christopher MJ, Petti AA, Rettig MP, et al. Immune Escape of Relapsed AML Cells after Allogeneic Transplantation. N Engl J Med 2018;379:2330-41. [PubMed: 30380364]

41. Vago L, Perna SK, Zanussi M, et al. Loss of mismatched HLA in leukemia after stem-cell transplantation. N Engl J Med 2009;361:478-88. [PubMed: 19641204]

42. Pollack MS, Heagney SD, Livingston PO, Fogh J. HLA-A, B, C and DR alloantigen expression on forty-six cultured human tumor cell lines. J Natl Cancer Inst 1981;66:1003-12. [PubMed: 7017212]

43. Forero A, Li Y, Chen D, et al. Expression of the MHC Class II Pathway in Triple-Negative Breast Cancer Tumor Cells Is Associated with a Good Prognosis and Infiltrating Lymphocytes. Cancer Immunol Res 2016;4:390-9. [PubMed: 26980599]

44. McCaw TR, Li M, Starenki D, et al. The expression of MHC class II molecules on murine breast tumors delays T-cell exhaustion, expands the T-cell repertoire, and slows tumor growth. Cancer Immunol Immunother 2019;68:175-88. [PubMed: 30334128]

45. Lovig T, Andersen SN, Thorstensen L, et al. Strong HLA-DR expression in microsatellite stable carcinomas of the large bowel is associated with good prognosis. Br J Cancer 2002;87:756-62. [PubMed: 12232760]

46. Johnson DB, Estrada MV, Salgado R, et al. Melanoma-specific MHC-II expression represents a tumour-autonomous phenotype and predicts response to anti-PD-1/PD-L1 therapy. Nat Commun 2016;7:10582. [PubMed: 26822383]

47. Tran E, Turcotte S, Gros A, et al. Cancer immunotherapy based on mutation-specific CD4+ T cells in a patient with epithelial cancer. Science 2014;344:641-5. [PubMed: 24812403] 
48. Stronen E, Toebes M, Kelderman S, et al. Targeting of cancer neoantigens with donor-derived T cell receptor repertoires. Science 2016;352:1337-41. [PubMed: 27198675]

49. Bleakley M, Otterud BE, Richardt JL, et al. Leukemia-associated minor histocompatibility antigen discovery using T-cell clones isolated by in vitro stimulation of naive CD8+ T cells. Blood 2010;115:4923-33. [PubMed: 20203263]

50. Sakuishi K, Apetoh L, Sullivan JM, Blazar BR, Kuchroo VK, Anderson AC. Targeting Tim-3 and PD-1 pathways to reverse T cell exhaustion and restore anti-tumor immunity. J Exp Med 2010;207:2187-94. [PubMed: 20819927]

51. Bentzen AK, Marquard AM, Lyngaa R, et al. Large-scale detection of antigen-specific T cells using peptide-MHC-I multimers labeled with DNA barcodes. Nat Biotechnol 2016;34:1037-45. [PubMed: 27571370]

52. Hu Z, Anandappa AJ, Sun J, et al. A cloning and expression system to probe T-cell receptor specificity and assess functional avidity to neoantigens. Blood 2018;132:1911-21. [PubMed: 30150207]

53. Kebriaei P, Singh H, Huls MH, et al. Phase I trials using Sleeping Beauty to generate CD19specific CAR T cells. J Clin Invest 2016;126:3363-76. [PubMed: 27482888]

54. Deniger DC, Pasetto A, Tran E, et al. Stable, Nonviral Expression of Mutated Tumor Neoantigenspecific T-cell Receptors Using the Sleeping Beauty Transposon/Transposase System. Mol Ther 2016;24:1078-89. [PubMed: 26945006]

55. Bishop DC, Xu N, Tse B, et al. PiggyBac-Engineered T Cells Expressing CD19-Specific CARs that Lack IgG1 Fc Spacers Have Potent Activity against B-ALL Xenografts. Mol Ther 2018;26:1883-95. [PubMed: 29861327]

56. Smith TT, Stephan SB, Moffett HF, et al. In situ programming of leukaemia-specific T cells using synthetic DNA nanocarriers. Nat Nanotechnol 2017;12:813-20. [PubMed: 28416815]

57. Bendle GM, Linnemann C, Hooijkaas AI, et al. Lethal graft-versus-host disease in mouse models of T cell receptor gene therapy. Nat Med 2010;16:565-70, 1p following 70. [PubMed: 20400962]

58. Sommermeyer D, Uckert W. Minimal amino acid exchange in human TCR constant regions fosters improved function of TCR gene-modified T cells. J Immunol 2010;184:6223-31. [PubMed: 20483785]

59. Ochi T, Fujiwara H, Okamoto S, et al. Novel adoptive T-cell immunotherapy using a WT1-specific TCR vector encoding silencers for endogenous TCRs shows marked antileukemia reactivity and safety. Blood 2011;118:1495-503. [PubMed: 21673345]

60. Manning TC, Schlueter CJ, Brodnicki TC, et al. Alanine scanning mutagenesis of an alphabeta T cell receptor: mapping the energy of antigen recognition. Immunity 1998;8:413-25. [PubMed: 9586632]

61. Udyavar A, Alli R, Nguyen P, Baker L, Geiger TL. Subtle affinity-enhancing mutations in a myelin oligodendrocyte glycoprotein-specific TCR alter specificity and generate new self-reactivity. J Immunol 2009;182:4439-47. [PubMed: 19299745]

62. Schmitt TM, Ragnarsson GB, Greenberg PD. T cell receptor gene therapy for cancer. Hum Gene Ther 2009;20:1240-8. [PubMed: 19702439]

63. Linette GP, Stadtmauer EA, Maus MV, et al. Cardiovascular toxicity and titin cross-reactivity of affinity-enhanced T cells in myeloma and melanoma. Blood 2013;122:863-71. [PubMed: 23770775]

64. Cameron BJ, Gerry AB, Dukes J, et al. Identification of a Titin-derived HLA-A1-presented peptide as a cross-reactive target for engineered MAGE A3-directed T cells. Sci Transl Med 2013;5:197ra03.

65. Huseby ES, Crawford F, White J, Marrack P, Kappler JW. Interface-disrupting amino acids establish specificity between $\mathrm{T}$ cell receptors and complexes of major histocompatibility complex and peptide. Nat Immunol 2006;7:1191-9. [PubMed: 17041605]

66. Stadinski BD, Trenh P, Smith RL, et al. A role for differential variable gene pairing in creating T cell receptors specific for unique major histocompatibility ligands. Immunity 2011;35:694-704. [PubMed: 22101158] 
67. Wucherpfennig KW, Gagnon E, Call MJ, Huseby ES, Call ME. Structural biology of the T-cell receptor: insights into receptor assembly, ligand recognition, and initiation of signaling. Cold Spring Harb Perspect Biol 2010;2:a005140. [PubMed: 20452950]

68. Schmitt TM, Aggen DH, Ishida-Tsubota K, Ochsenreither S, Kranz DM, Greenberg PD. Generation of higher affinity $\mathrm{T}$ cell receptors by antigen-driven differentiation of progenitor $\mathrm{T}$ cells in vitro. Nat Biotechnol 2017;35:1188-95. [PubMed: 29106410]

69. Dossa RG, Cunningham T, Sommermeyer D, et al. Development of T-cell immunotherapy for hematopoietic stem cell transplantation recipients at risk of leukemia relapse. Blood 2018;131:108-20. [PubMed: 29051183]

70. Giuntoli RL 2nd, Lu J, Kobayashi H, Kennedy R, Celis E. Direct costimulation of tumor-reactive CTL by helper T cells potentiate their proliferation, survival, and effector function. Clin Cancer Res 2002;8:922-31. [PubMed: 11895927]

71. Hung K, Hayashi R, Lafond-Walker A, Lowenstein C, Pardoll D, Levitsky H. The central role of CD4(+) T cells in the antitumor immune response. J Exp Med 1998;188:2357-68. [PubMed: 9858522]

72. Kennedy R, Celis E. Multiple roles for CD4+ T cells in anti-tumor immune responses. Immunol Rev 2008;222:129-44. [PubMed: 18363998]

73. Morris EC, Tsallios A, Bendle GM, Xue SA, Stauss HJ. A critical role of T cell antigen receptortransduced MHC class I-restricted helper T cells in tumor protection. Proc Natl Acad Sci U S A 2005;102:7934-9. [PubMed: 15908507]

74. van der Veken LT, Hagedoorn RS, van Loenen MM, Willemze R, Falkenburg JH, Heemskerk MH. Alphabeta T-cell receptor engineered gammadelta $\mathrm{T}$ cells mediate effective antileukemic reactivity. Cancer Res 2006;66:3331-7. [PubMed: 16540688]

75. Di Stasi A, Tey SK, Dotti G, et al. Inducible apoptosis as a safety switch for adoptive cell therapy. N Engl J Med 2011;365:1673-83. [PubMed: 22047558]

76. Ramos CA, Asgari Z, Liu E, et al. An inducible caspase 9 suicide gene to improve the safety of mesenchymal stromal cell therapies. Stem Cells 2010;28:1107-15. [PubMed: 20506146]

77. Straathof KC, Pule MA, Yotnda P, et al. An inducible caspase 9 safety switch for T-cell therapy. Blood 2005;105:4247-54. [PubMed: 15728125]

78. Tey SK, Dotti G, Rooney CM, Heslop HE, Brenner MK. Inducible caspase 9 suicide gene to improve the safety of allodepleted T cells after haploidentical stem cell transplantation. Biol Blood Marrow Transplant 2007;13:913-24. [PubMed: 17640595]

79. Zhou X, Di Stasi A, Tey SK, et al. Long-term outcome after haploidentical stem cell transplant and infusion of T cells expressing the inducible caspase 9 safety transgene. Blood 2014;123:3895-905. [PubMed: 24753538]

80. Zhou X, Naik S, Dakhova O, Dotti G, Heslop HE, Brenner MK. Serial Activation of the Inducible Caspase 9 Safety Switch After Human Stem Cell Transplantation. Mol Ther 2016;24:823-31. [PubMed: 26708005]

81. Kerkar SP, Muranski P, Kaiser A, et al. Tumor-specific CD8+ T cells expressing interleukin-12 eradicate established cancers in lymphodepleted hosts. Cancer Res 2010;70:6725-34. [PubMed: 20647327]

82. Pegram HJ, Lee JC, Hayman EG, et al. Tumor-targeted T cells modified to secrete IL-12 eradicate systemic tumors without need for prior conditioning. Blood 2012;119:4133-41. [PubMed: 22354001]

83. Zhang L, Morgan RA, Beane JD, et al. Tumor-infiltrating lymphocytes genetically engineered with an inducible gene encoding interleukin-12 for the immunotherapy of metastatic melanoma. Clin Cancer Res 2015;21:2278-88. [PubMed: 25695689]

84. Alsaieedi A, Holler A, Velica P, Bendle G, Stauss HJ. Safety and efficacy of Tet-regulated IL-12 expression in cancer-specific T cells. Oncoimmunology 2019;8:1542917. [PubMed: 30723575]

85. Borkner L, Kaiser A, van de Kasteele W, et al. RNA interference targeting programmed death receptor-1 improves immune functions of tumor-specific T cells. Cancer Immunol Immunother 2010;59:1173-83. [PubMed: 20349059]

86. Su S, Hu B, Shao J, et al. CRISPR-Cas9 mediated efficient PD-1 disruption on human primary T cells from cancer patients. Sci Rep 2016;6:20070. [PubMed: 26818188] 
87. Oda SK, Daman AW, Garcia NM, et al. A CD200R-CD28 fusion protein appropriates an inhibitory signal to enhance T-cell function and therapy of murine leukemia. Blood 2017;130:2410-9. [PubMed: 29042364]

88. Nishimura CD, Brenner DA, Mukherjee M, et al. c-MPL provides tumor-targeted T-cell receptortransgenic T cells with costimulation and cytokine signals. Blood 2017;130:2739-49. [PubMed: 29079582]

89. Torikai H, Reik A, Soldner F, et al. Toward eliminating HLA class I expression to generate universal cells from allogeneic donors. Blood 2013;122:1341-9. [PubMed: 23741009]

90. Zhang J, Wang L. The Emerging World of TCR-T Cell Trials Against Cancer: A Systematic Review. Technol Cancer Res Treat 2019;18:1533033819831068. [PubMed: 30798772]

91. Inoue K, Ogawa H, Sonoda Y, et al. Aberrant overexpression of the Wilms tumor gene (WT1) in human leukemia. Blood 1997;89:1405-12. [PubMed: 9028964]

92. Ohminami H, Yasukawa M, Fujita S. HLA class I-restricted lysis of leukemia cells by a CD8(+) cytotoxic T-lymphocyte clone specific for WT1 peptide. Blood 2000;95:286-93. [PubMed: 10607714]

93. Gao L, Bellantuono I, Elsasser A, et al. Selective elimination of leukemic CD34(+) progenitor cells by cytotoxic T lymphocytes specific for WT1. Blood 2000;95:2198-203. [PubMed: 10733485]

94. Rezvani K, Yong AS, Savani BN, et al. Graft-versus-leukemia effects associated with detectable Wilms tumor-1 specific T lymphocytes after allogeneic stem-cell transplantation for acute lymphoblastic leukemia. Blood 2007;110:1924-32. [PubMed: 17505014]

95. Ho WY, Nguyen HN, Wolfl M, Kuball J, Greenberg PD. In vitro methods for generating CD8+ Tcell clones for immunotherapy from the naive repertoire. J Immunol Methods 2006;310:40-52. [PubMed: 16469329]

96. Weber G, Gerdemann U, Caruana I, et al. Generation of multi-leukemia antigen-specific T cells to enhance the graft-versus-leukemia effect after allogeneic stem cell transplant. Leukemia 2013;27:1538-47. [PubMed: 23528871]

97. Chapuis AG, Ragnarsson GB, Nguyen HN, et al. Transferred WT1-reactive CD8+ T cells can mediate antileukemic activity and persist in post-transplant patients. Sci Transl Med 2013;5:174ra27.

98. Chapuis AG, Egan D, Bar M, et al. EBV-Specific Donor Cells Transduced to Express a HighAffinity WT1 TCR Can Prevent Recurrence in Post-HCT Patients with High-Risk AML. Blood 2016;128:1001.

99. Chapuis AG, Egan D, Bar M, et al. T Cell Receptor Gene Therapy Targeting WT1 Prevents Acute Myeloid Leukemia Relapse Post-Transplant. Nat Med 2019 (accepted).

100. Tawara I, Kageyama S, Miyahara Y, et al. Safety and persistence of WT1-specific T-cell receptor gene-transduced lymphocytes in patients with AML and MDS. Blood 2017;130:1985-94. [PubMed: 28860210]

101. Qin Y, Zhu H, Jiang B, et al. Expression patterns of WT1 and PRAME in acute myeloid leukemia patients and their usefulness for monitoring minimal residual disease. Leuk Res 2009;33:384-90. [PubMed: 18950857]

102. van Baren N, Chambost H, Ferrant A, et al. PRAME, a gene encoding an antigen recognized on a human melanoma by cytolytic T cells, is expressed in acute leukaemia cells. Br J Haematol 1998;102:1376-9. [PubMed: 9753074]

103. Amir AL, van der Steen DM, van Loenen MM, et al. PRAME-specific Allo-HLA-restricted T cells with potent antitumor reactivity useful for therapeutic T-cell receptor gene transfer. Clin Cancer Res 2011;17:5615-25. [PubMed: 21771875]

104. Weis MW C; Ellinger C; Wilde S; Schendel DJ Isolation and characterization of a PRAMEspecific TCR with high avidity, potent antitumor efficacy and a favorable preclinical safety profile. American Association for Cancer Research Annual Meeting 2017; Abstract 4977.

105. Marijt WA, Heemskerk MH, Kloosterboer FM, et al. Hematopoiesis-restricted minor histocompatibility antigens HA-1- or HA-2-specific T cells can induce complete remissions of relapsed leukemia. Proc Natl Acad Sci U S A 2003;100:2742-7. [PubMed: 12601144]

106. Adida C, Recher C, Raffoux E, et al. Expression and prognostic significance of survivin in de novo acute myeloid leukaemia. Br J Haematol 2000;111:196-203. [PubMed: 11091201] 
107. Carter BZ, Qiu Y, Huang X, et al. Survivin is highly expressed in CD34(+)38(-) leukemic stem/ progenitor cells and predicts poor clinical outcomes in AML. Blood 2012;120:173-80. [PubMed: 22645176]

108. Tamm I, Richter S, Oltersdorf D, et al. High expression levels of x-linked inhibitor of apoptosis protein and survivin correlate with poor overall survival in childhood de novo acute myeloid leukemia. Clin Cancer Res 2004;10:3737-44. [PubMed: 15173080]

109. Adida C, Haioun C, Gaulard P, et al. Prognostic significance of survivin expression in diffuse large B-cell lymphomas. Blood 2000;96:1921-5. [PubMed: 10961895]

110. Schlette EJ, Medeiros LJ, Goy A, Lai R, Rassidakis GZ. Survivin expression predicts poorer prognosis in anaplastic large-cell lymphoma. J Clin Oncol 2004;22:1682-8. [PubMed: 15117990]

111. Leisegang M, Wilde S, Spranger S, et al. MHC-restricted fratricide of human lymphocytes expressing survivin-specific transgenic T cell receptors. J Clin Invest 2010;120:3869-77. [PubMed: 20978348]

112. Arber C, Feng X, Abhyankar H, et al. Survivin-specific T cell receptor targets tumor but not T cells. J Clin Invest 2015;125:157-68. [PubMed: 25415440]

113. Kim NW, Piatyszek MA, Prowse KR, et al. Specific association of human telomerase activity with immortal cells and cancer. Science 1994;266:2011-5. [PubMed: 7605428]

114. Counter CM, Gupta J, Harley CB, Leber B, Bacchetti S. Telomerase activity in normal leukocytes and in hematologic malignancies. Blood 1995;85:2315-20. [PubMed: 7727765]

115. Broccoli D, Young JW, de Lange T. Telomerase activity in normal and malignant hematopoietic cells. Proc Natl Acad Sci U S A 1995;92:9082-6. [PubMed: 7568077]

116. Tajima K, Ito Y, Demachi A, et al. Interferon-gamma differentially regulates susceptibility of lung cancer cells to telomerase-specific cytotoxic T lymphocytes. Int J Cancer 2004;110:403-12. [PubMed: 15095306]

117. Miyazaki Y, Fujiwara H, Asai H, et al. Development of a novel redirected T-cell-based adoptive immunotherapy targeting human telomerase reverse transcriptase for adult T-cell leukemia. Blood 2013;121:4894-901. [PubMed: 23641014]

118. Ugel S, Scarselli E, Iezzi M, et al. Autoimmune B-cell lymphopenia after successful adoptive therapy with telomerase-specific T lymphocytes. Blood 2010;115:1374-84. [PubMed: 19903903]

119. Sandri S, Bobisse S, Moxley K, et al. Feasibility of Telomerase-Specific Adoptive T-cell Therapy for B-cell Chronic Lymphocytic Leukemia and Solid Malignancies. Cancer Res 2016;76:2540 51. [PubMed: 27197263]

120. Sandri S, De Sanctis F, Lamolinara A, et al. Effective control of acute myeloid leukaemia and acute lymphoblastic leukaemia progression by telomerase specific adoptive T-cell therapy. Oncotarget 2017;8:86987-7001. [PubMed: 29152058]

121. Jahn L, Hombrink P, Hagedoorn RS, et al. TCR-based therapy for multiple myeloma and other Bcell malignancies targeting intracellular transcription factor BOB1. Blood 2017;129:1284-95. [PubMed: 28053195]

122. Jahn L, van der Steen DM, Hagedoorn RS, et al. Generation of CD20-specific TCRs for TCR gene therapy of CD20low B-cell malignancies insusceptible to CD20-targeting antibodies. Oncotarget 2016;7:77021-37. [PubMed: 27776339]

123. Jahn L, Hagedoorn RS, van der Steen DM, et al. A CD22-reactive TCR from the T-cell allorepertoire for the treatment of acute lymphoblastic leukemia by TCR gene transfer. Oncotarget 2016;7:71536-47. [PubMed: 27689397]

124. Hamada M, Yakushijin Y, Ohtsuka M, Kakimoto M, Yasukawa M, Fujita S. Aurora2/BTAK/ STK15 is involved in cell cycle checkpoint and cell survival of aggressive non-Hodgkin's lymphoma. Br J Haematol 2003;121:439-47. [PubMed: 12716366]

125. Ochi T, Fujiwara H, Suemori K, et al. Aurora-A kinase: a novel target of cellular immunotherapy for leukemia. Blood 2009;113:66-74. [PubMed: 18820130]

126. Nagai K, Ochi T, Fujiwara H, et al. Aurora kinase A-specific T-cell receptor gene transfer redirects T lymphocytes to display effective antileukemia reactivity. Blood 2012;119:368-76. [PubMed: 22025529] 
127. Casey NP, Fujiwara H, Ochi T, Yasukawa M. Novel immunotherapy for adult T-cell leukemia/ lymphoma: Targeting aurora kinase A. Oncoimmunology 2016;5:e1239006. [PubMed: 27999761]

128. Lawrence MS, Stojanov P, Polak P, et al. Mutational heterogeneity in cancer and the search for new cancer-associated genes. Nature 2013;499:214-8. [PubMed: 23770567]

129. Biernacki MA, Foster KA, Coon ME, et al. An Epitope from the Recurrent CBFB-MYH11 Fusion Protein Is a Highly Immunogenic AML Neoantigen In: Transplantation and Cellular Therapies Annual Meeting; 20192 20-24; Houston, TX Abstract LBA29.

130. van der Lee DI, Reijmers RM, Honders MW, et al. Mutated nucleophosmin 1 as immunotherapy target in acute myeloid leukemia. J Clin Invest 2019.

131. Berlin C, Kowalewski DJ, Schuster H, et al. Mapping the HLA ligandome landscape of acute myeloid leukemia: a targeted approach toward peptide-based immunotherapy. Leukemia 2015;29:647-59. [PubMed: 25092142]

132. Bilich T, Nelde A, Bichmann L, et al. The HLA ligandome landscape of chronic myeloid leukemia delineates novel T-cell epitopes for immunotherapy. Blood 2019;133:550-65. [PubMed: 30530751]

133. Nelde A, Kowalewski DJ, Backert L, et al. HLA ligandome analysis of primary chronic lymphocytic leukemia (CLL) cells under lenalidomide treatment confirms the suitability of lenalidomide for combination with T-cell-based immunotherapy. Oncoimmunology 2018;7:e1316438. [PubMed: 29632711]

134. Abelin JG, Keskin DB, Sarkizova S, et al. Mass Spectrometry Profiling of HLA-Associated Peptidomes in Mono-allelic Cells Enables More Accurate Epitope Prediction. Immunity 2017;46:315-26. [PubMed: 28228285]

135. Hawkins OE, Vangundy RS, Eckerd AM, et al. Identification of breast cancer peptide epitopes presented by HLA-A*0201. J Proteome Res 2008;7:1445-57. [PubMed: 18345606]

136. Trolle T, McMurtrey CP, Sidney J, et al. The Length Distribution of Class I-Restricted T Cell Epitopes Is Determined by Both Peptide Supply and MHC Allele-Specific Binding Preference. J Immunol 2016;196:1480-7. [PubMed: 26783342]

137. Dash P, Fiore-Gartland AJ, Hertz T, et al. Quantifiable predictive features define epitope-specific T cell receptor repertoires. Nature 2017;547:89-93. [PubMed: 28636592]

138. Grupp SA, Kalos M, Barrett D, et al. Chimeric antigen receptor-modified T cells for acute lymphoid leukemia. N Engl J Med 2013;368:1509-18. [PubMed: 23527958]

139. Maude SL, Frey N, Shaw PA, et al. Chimeric antigen receptor T cells for sustained remissions in leukemia. N Engl J Med 2014;371:1507-17. [PubMed: 25317870]

140. Ma Q, Garber HR, Lu S, et al. A novel TCR-like CAR with specificity for PR1/HLA-A2 effectively targets myeloid leukemia in vitro when expressed in human adult peripheral blood and cord blood T cells. Cytotherapy 2016;18:985-94. [PubMed: 27265873]

141. Romero P, Dunbar PR, Valmori D, et al. Ex vivo staining of metastatic lymph nodes by class I major histocompatibility complex tetramers reveals high numbers of antigen-experienced tumorspecific cytolytic T lymphocytes. J Exp Med 1998;188:1641-50. [PubMed: 9802976]

142. Zippelius A, Pittet MJ, Batard P, et al. Thymic selection generates a large T cell pool recognizing a self-peptide in humans. J Exp Med 2002;195:485-94. [PubMed: 11854361]

143. Coulie PG, Van den Eynde BJ, van der Bruggen P, Boon T. Tumour antigens recognized by $\mathrm{T}$ lymphocytes: at the core of cancer immunotherapy. Nat Rev Cancer 2014;14:135-46. [PubMed: 24457417]

144. Ikeda H, Lethe B, Lehmann F, et al. Characterization of an antigen that is recognized on a melanoma showing partial HLA loss by CTL expressing an NK inhibitory receptor. Immunity 1997;6:199-208. [PubMed: 9047241] 
TIL

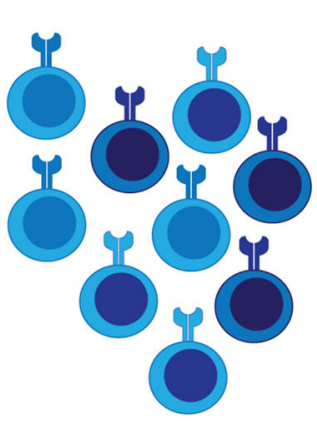

CAR-T

TCR-T
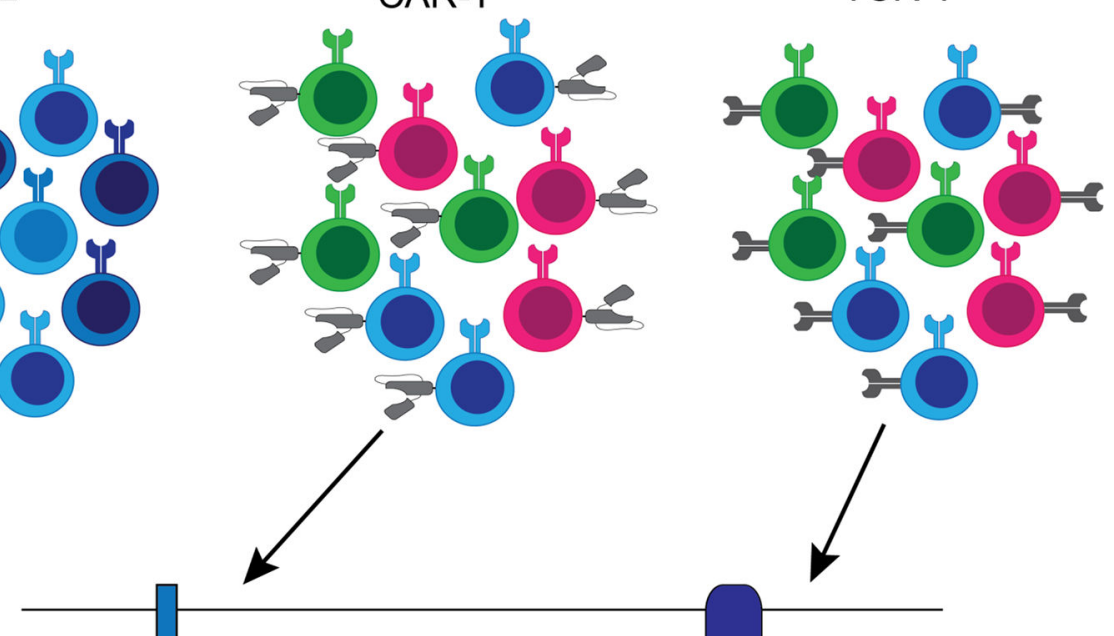

costimulatory domain $\operatorname{CD} 3 \zeta$

SCFV

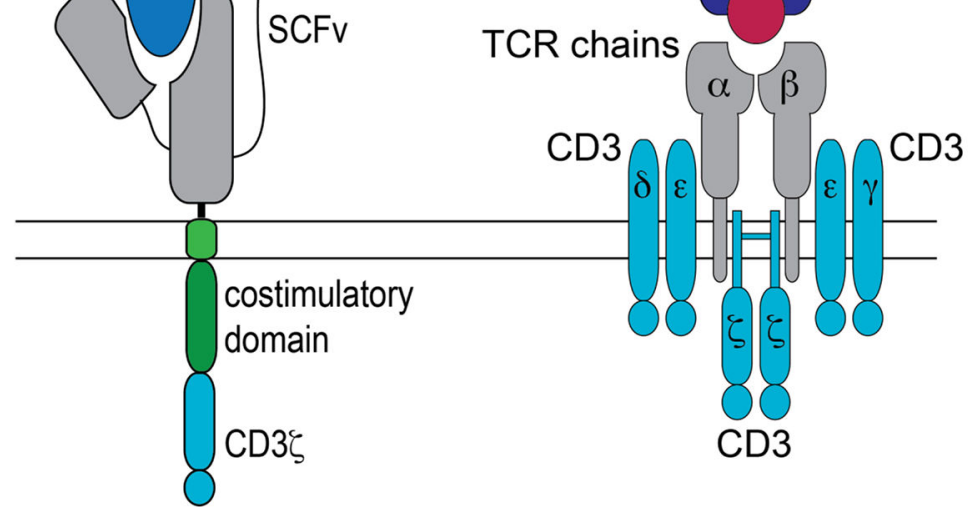

Figure 1.

Types of adoptive $\mathrm{T}$ cell therapy 


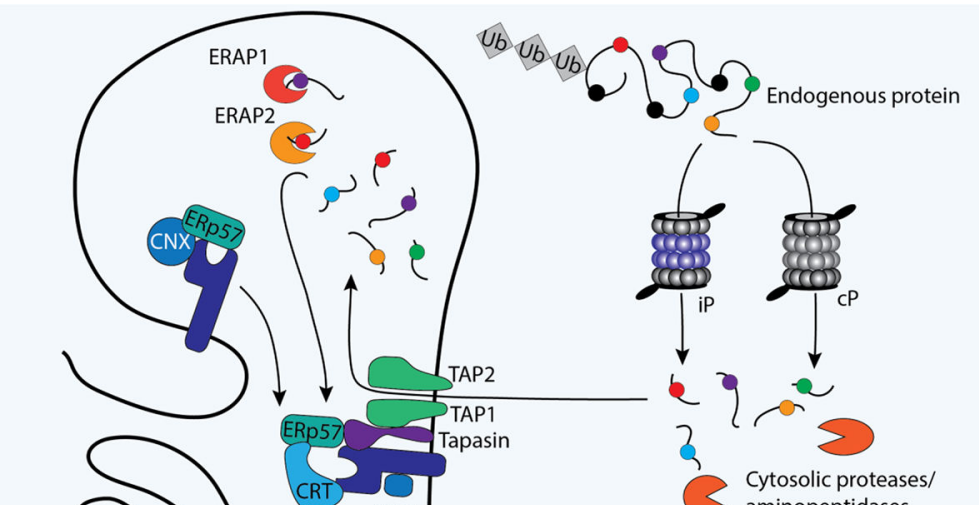

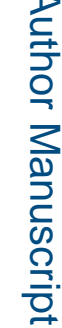

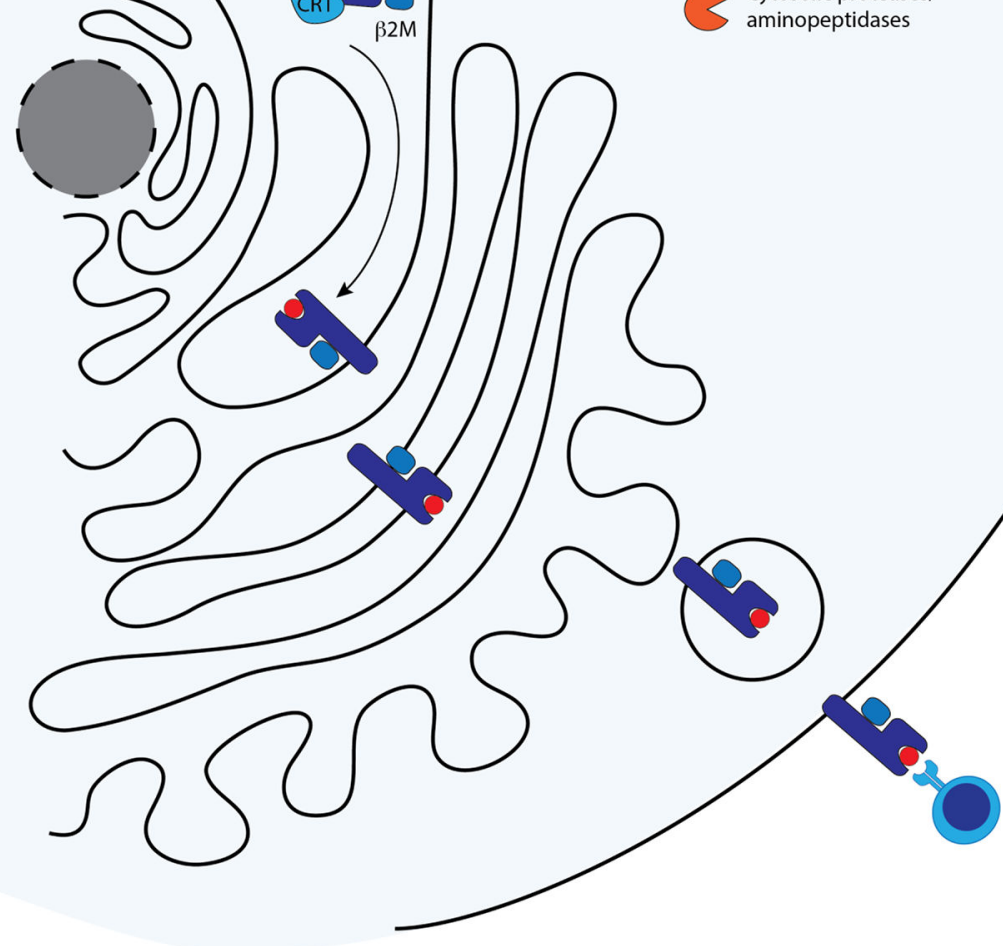

Figure 2.

Antigen processing and presentation 


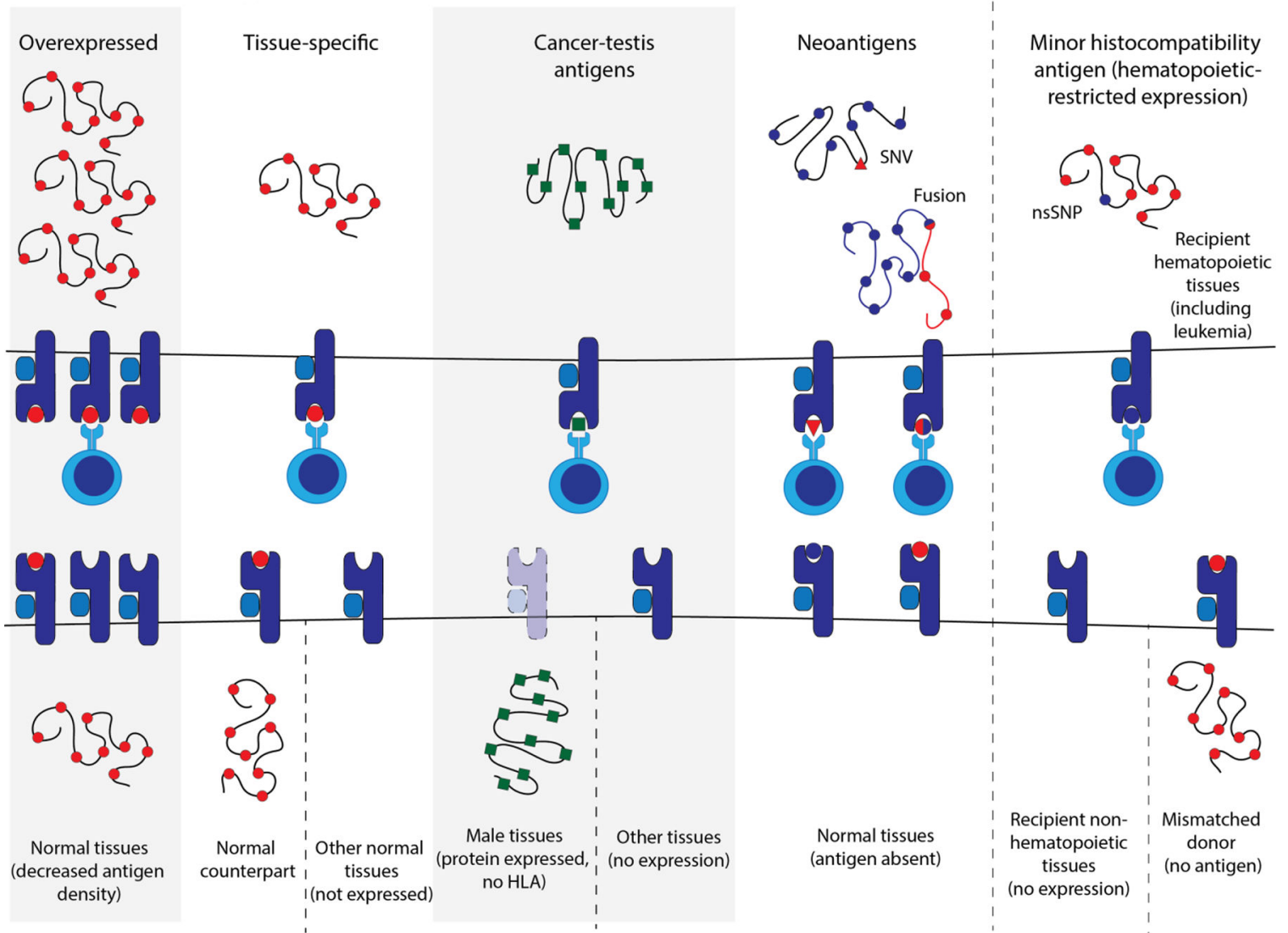

Figure 3.

Categories of tumor-associated antigens 


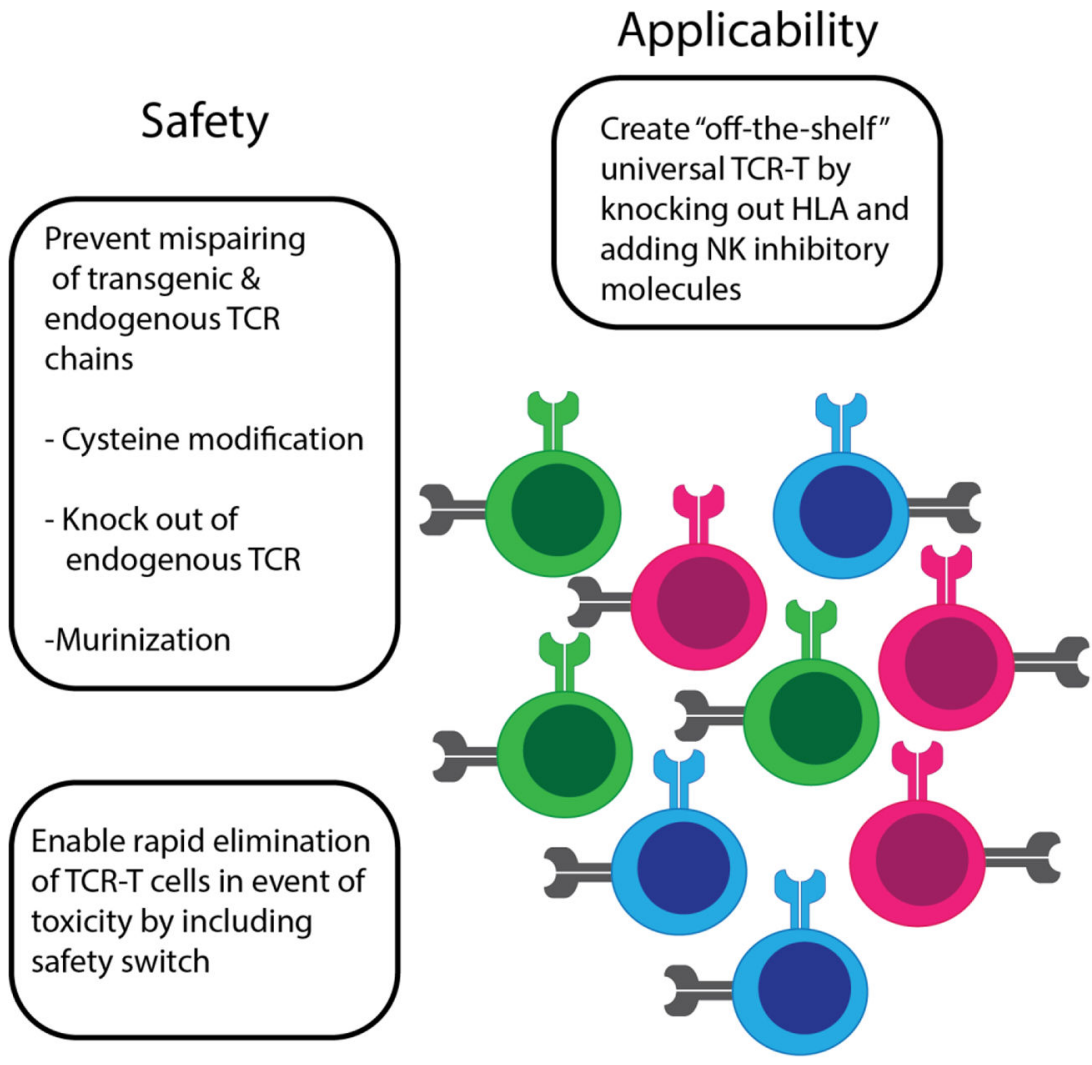

\section{Effectiveness}

Increase affinity of TCR for antigen with affinity maturation

Allow $\mathrm{CD}^{+} \mathrm{T}$ cell recognition of class I restricted antigens by adding $\mathrm{CD} 8$ coreceptor - CD4 ${ }^{+}$help - Improved persistence

Enable rapid elimination of TCR-T cells in event of toxicity by including safety switch

Construct modifications to enhance TCR-T cells
Protect from exhaustion by knocking out exhaustion molecules or converting into stimulatory signal

Enhance anti-tumor function with cytokine expression (e.g., IL-12) 
Table 1.

Approaches to adoptive T cell immunotherapies

\begin{tabular}{|l|l|l|}
\hline & Advantages & Disadvantages \\
\hline TIL & $\begin{array}{l}\text { Polyclonal (reduce potential for escape through } \\
\text { antigen loss); targets from intracellular and cell } \\
\text { surface proteins }\end{array}$ & $\begin{array}{l}\text { T cell specificity generally unknown; cannot be generated for all patients; not } \\
\text { well established for hematologic malignancies; patient specific }\end{array}$ \\
\hline TCR-T & $\begin{array}{l}\text { Targets derived from intracellular and cell surface } \\
\text { proteins; defined specificity }\end{array}$ & $\begin{array}{l}\text { HLA restriction; tumor escape through antigen loss (altered processing of } \\
\text { peptides, HLA downregulation) }\end{array}$ \\
\hline CAR-T & No HLA-restriction; defined specificity & $\begin{array}{l}\text { Cell surface targets only; tumor escape through antigen loss (downregulation } \\
\text { or loss of target protein) }\end{array}$ \\
\hline
\end{tabular}


Table 2.

Categories of TAAs for the development of TCR-T immunotherapy

\begin{tabular}{|c|c|c|c|c|c|}
\hline & Overexpressed & Lineage-restricted & Cancer-testis antigens & Neoantigens & $\begin{array}{c}\text { Minor } \\
\text { histocompatibility } \\
\text { (H) antigens }\end{array}$ \\
\hline Antigen derived from & $\begin{array}{l}\text { Wild-type } \\
\text { protein with } \\
\text { relatively } \\
\text { increased } \\
\text { expression in } \\
\text { malignant cells }\end{array}$ & $\begin{array}{l}\text { Wild-type protein } \\
\text { expressed in } \\
\text { malignant cells and } \\
\text { normal counterparts }\end{array}$ & $\begin{array}{l}\text { Wild-type protein } \\
\text { expressed only in } \\
\text { malignant cells and } \\
\text { germline cells }\end{array}$ & $\begin{array}{l}\text { Abnormal } \\
\text { protein created } \\
\text { by cancer- } \\
\text { specific } \\
\text { mutation, gene } \\
\text { fusion, frame } \\
\text { shift or } \\
\text { abnormal } \\
\text { splicing, or } \\
\text { peptide created } \\
\text { by abnormal } \\
\text { antigen } \\
\text { processing }\end{array}$ & $\begin{array}{l}\text { Polymorphic normal } \\
\text { peptides created by } \\
\text { polymorphisms that } \\
\text { differ between donor } \\
\text { and recipient in } \\
\text { allogeneic } \\
\text { hematopoietic cell } \\
\text { transplantation (HCT) }\end{array}$ \\
\hline $\begin{array}{l}\text { Specificity for } \\
\text { malignant cells }\end{array}$ & Lowest & Low & Moderate & Highest & $\begin{array}{l}\text { Hematopoietic- } \\
\text { resetricted minor } \mathrm{H} \\
\text { antigens become } \\
\text { leukemia-specific } \\
\text { following allo-HCT }\end{array}$ \\
\hline $\begin{array}{l}\text { Potential for on-target } \\
\text { off tumor toxicity }\end{array}$ & High & $\begin{array}{l}\text { Moderate/high (may } \\
\text { be acceptable if } \\
\text { normal counterpart is } \\
\text { dispensable) }\end{array}$ & $\begin{array}{c}\text { Low } \\
\text { (Testis/germline lissues } \\
\text { lack HLA) }\end{array}$ & Lowest & Variable \\
\hline $\begin{array}{l}\text { Breadth of potential } \\
\text { applicability }\end{array}$ & High & High & Moderate/high & Low & $\begin{array}{l}\text { Moderate/high (only } \\
\text { for relapses after allo- } \\
\text { HCT) }\end{array}$ \\
\hline
\end{tabular}


Table 3.

Examples of TAA in hematologic malignancies and solid tumors

\begin{tabular}{|c|c|c|c|c|c|}
\hline Category of TAA & Cancer types & Examples & Diseases & Other tissues & References \\
\hline \multirow[t]{4}{*}{ Overexpressed } & \multirow[t]{4}{*}{ Hematologic } & WT1 & AML, MDS & $\begin{array}{c}\text { Kidney (podocytes), CD34 } \\
\text { cells }\end{array}$ & 91 \\
\hline & & Survivin & AML, ALL, MDS & None in adult tissues & 3 \\
\hline & & hTERT & ALL, AML, CLL & Ovaries, testis & $113-115$ \\
\hline & & BOB1 & $\begin{array}{l}\text { B cell leukemias and } \\
\text { lymphomas, multiple } \\
\text { myeloma }\end{array}$ & Normal B cells & 121 \\
\hline \multirow[t]{5}{*}{ Lineage-restricted } & \multirow[t]{2}{*}{ Hematologic } & $\mathrm{CD} 20$ & Lymphoma & \multirow[t]{2}{*}{ Normal B cells } & 122 \\
\hline & & $\mathrm{CD} 22$ & ALL & & 123 \\
\hline & \multirow[t]{3}{*}{ Solid tumor } & MART-1/MelanA & \multirow[t]{3}{*}{ Melanoma } & \multirow[t]{3}{*}{ Normal melanocytes } & 141,142 \\
\hline & & Tyrosinase & & & \multirow[t]{2}{*}{ Reviewed in 143} \\
\hline & & gp100 & & & \\
\hline \multirow[t]{3}{*}{ Cancer-testis antigens } & \multirow[t]{2}{*}{ Hematologic } & PRAME & $\begin{array}{l}\text { AML, ALL, MDS, } \\
\text { multiple solid tumors }\end{array}$ & $\begin{array}{l}\text { Adrenals, ovaries, } \\
\text { endometrium, testis }\end{array}$ & 144,102 \\
\hline & & Aurora kinase A & AML, CML, ATL & Testis & 125,126127 \\
\hline & Solid tumor & MAGE family & $\begin{array}{l}\text { Melanoma, lung, } \\
\text { breast, colorectal, } \\
\text { prostate }\end{array}$ & Testis, brain (MAGEA12) & Reviewed in 143 \\
\hline \multirow[t]{2}{*}{ Neoantigens } & \multirow[t]{2}{*}{ Hematologic } & NPM1 & \multirow[t]{2}{*}{ AML } & \multirow[t]{2}{*}{ None } & 130 \\
\hline & & CBFB-MYH11 & & & 129 \\
\hline $\begin{array}{c}\text { Leukemia-associated } \\
\text { minor } \\
\text { histocompatibility }(\mathrm{H}) \\
\text { antigens }\end{array}$ & Hematologic & HA-1 & $\begin{array}{l}\text { Relapsed hematologic } \\
\text { malignancies after } \\
\text { allo-HCT }\end{array}$ & Hematopoietic & 69 \\
\hline
\end{tabular}

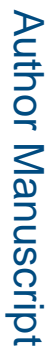

